\title{
PROPOSED BYCATCH-REDUCTION MODIFICATIONS OF SHRIMP FYKE NETS USED IN SOUTH AMERICAN LAGOONS
}

\author{
Eduardo G.G. FARIAS ${ }^{1 *}$, Antônio C. PEREIRA-JÚNIOR ${ }^{1}$, Marcelo M. DOMINGOS ${ }^{1}$, \\ and David V. DANTAS ${ }^{1,2}$ \\ ${ }^{1}$ Grupo de Gestão, Ecologia e Tecnologia Marinha (GTMar/UDESC), Departamento de Engenharia de Pesca \\ e Ciências Biológicas (DEPB), Universidade do Estado de Santa Catarina (UDESC), Laguna SC, Brazil \\ ${ }^{2}$ Programa de Pós-Graduação em Planejamento Territorial e Desenvolvimento Socioambiental (PPGPLAN) - \\ UDESC/FAED, Laguna SC, Brazil
}

Farias E.G.G., Pereira-Júnior A.C., Domingos M.M., Dantas D.V. 2019. Proposed bycatch-reduction modifications of shrimp fyke nets used in South American lagoons. Acta Ichthyol. Piscat. 49 (1): 1-7.

Background. Shrimp fisheries using fyke nets have been associated with a massive acquisition of teleost fishes as bycatch, potentially resulting in the decimation of their stocks. Based on this assumption, the presently reported study intended to test an alternative modification of a commonly used fyke net, in order to minimize the impact of its low selectivity.

Materials and methods. To evaluate the alternative design proposed in this work, a total of 44 sampling efforts, including 22 with a control gear (CG) and 22 with a modified gear (MG), were conducted at a subtropical coastal lagoon system located in southern Brazil. In all trials, the fyke nets were installed at the fishing area approximately at 18:00 $\mathrm{h}$ and removed approximately at 06:00 $\mathrm{h}$. The duration of each trial was nearly $12 \mathrm{~h}$, which was similar to the catching time preferred by local fishermen.

Results. Bycatch (BC) was preponderant in both modalities but the results showed that MG presented a reduction by 66 percentage points in $\mathrm{BC}$ catches, being more selective than CG. Additionally, the non-parametric test showed no significant differences of shrimp catches between the fishing gears used (MG and CG). So, the tested bycatch reduction devices (BRD) reduced the bony fishes acquisition preserving the volume of the target catch. Conclusion. The vertical opening reduction due the adoption of guiding panel + fan upper panel contributed to bycatch reduction, being a consistent $\mathrm{BRD}$ to reduce the potential impacts of this fishing gear over the bony fishes stocks.

Keywords: responsible fisheries, shrimp, bycatch reduction, fisheries engineering, passive fishing gear, fyke net, selectivity

\section{INTRODUCTION}

Transitional coastal wetlands, such as estuaries, coastal lagoons, mangroves, or salt marshes, are among the richest aquatic ecosystems in the world, supporting a diversity of organisms, many of them of commercial value (Barletta et al. 2017). In this sense, the penaeid shrimp fisheries is one of the most relevant economic activities in these coastal zones, representing almost $80 \%$ of global shrimp catches with wide range occurrence around the world (Broadhurst 2000, D’Incao et al. 2002).

In South America, bottom trawls are the main fishing gear used for shrimp catches in the marine environment (Branco and Verani 2006, Cattani et al. 2012, Domingos et al. 2016, Vieira et al. 2017). On the other hand, shrimp traps or shrimp fyke nets are largely used in estuarine and coastal lagoons (Vianna and D'Incao 2006, Benedet et al. 2010). Regardless of the nature of catch, both fishing gears the trawls (active) and shrimp fyke nets (passive) yield a massive bycatch (Loebmann and Vieira 2006).

In order to minimize the bycatch in shrimp fisheries, many researchers have been suggesting the development of bycatch reduction devices (BRD) as an alternative to fisheries management (Andrew et al. 1993, Broadhurst and Kennelly 1996, Broadhurst 2000). The overwhelming majority of published records was devoted to BRDs in shrimp trawls and only few efforts were intended to reduce bycatch in other shrimp fisheries (Larocque et al. 2012, Colotelo et al. 2013, Soeth et al. 2015). It has been widely known that shrimp fyke nets catch an excessive number of different bony fishes that usually are discarded after the fishing activity but only few authors suggested low-cost alternatives to reduce this problem (Vianna and D'Incao 2006, Soeth et al. 2015). 
Considering the relevance of this subject, the presently reported study suggests an alternative design of shrimp fyke nets, in order to minimize the impacts caused by the low selectivity of this fishing gear to contribute to the development of a new BRD, that reconciles technology and sustainability.

\section{MATERIALS AND METHODS}

Study area. The presently reported study was carried out in the Laguna Estuarine Complex (LEC) (Barletta et al. 2017) is located in southern Brazil (central coordinates: $\left.048.75^{\circ} \mathrm{W}, 28.35^{\circ} \mathrm{S}\right)$, formed by the Santo Antonio dos Anjos, Imaruí, and Mirim lagoons (18 400 ha). More details about LES abiotic factors can be found in Barletta et al. 2017. Each lagoon is linked to the other by small channels, and the water flows to the sea through a single channel (for the map of the area see Marques 2011). The estuary is located in a strip of coastal plains, and it is a typical choked lagoon, where the salinity ecocline is formed by the connection between the sea and the Santo Antonio dos Anjos Lagoon. The estuary receives freshwater from the Tubarão River basin which discharges directly in the low estuary. The middle estuary, where the presently reported study was carried, presents limnetic to oligohaline conditions, with a seasonal influence of rainfall patterns (Barletta et al. 2017). Control (CG) and modified (MG) shrimp fyke nets. This study was performed during the 2016 shrimpfishing season in the Laguna Estuarine Complex (LEC). In the LEC, the shrimp fyke nets are the main artisanal fishing gear to catch the juvenile population of pink shrimp (Farfantepenaeus paulensis and Farfantepenaeus brasiliensis). The fyke nets are allocated in shallows zones $(<1.5 \mathrm{~m})$ preferably close to widgeon grass (Ruppia maritima) and/or close to sheltered areas. Notably, this fishing ground supports different young estuarinedependent species, and occasionally adult, estuarineresident, marine and freshwater species.

Shrimp fyke nets have a geometric shape similar to bottom trawls, that is, a conical appearance, two wings, and a codend. However, they are passive gears with its wings and codend attached to wooden stakes and submerged in estuarine shallow waters during the night period. On top of the codend wooden stake a $3 \mathrm{~W}$ white light-emitting diode (LED) lamp is installed to attract the shrimp into the gear. Another structural difference can be observed due to valves sequences (two or three) in fyke nets bodies with a distance of $0.5 \mathrm{~m}$ of between them to facilitate the shrimp catch. The shrimp fyke nets adopted in this study had the typical dimensions of such nets commonly used in the LEC (Table 1).

In order to combine selectivity and low cost, the BRD proposed consists of two adaptations in a regular shrimp fyke net:

Substitution of a regular upper panel (PE multi and 24 $\mathrm{mm}$ ) with a fan panel that consists of polyethylene ropes connected between a cork line to the top portion of the ring of the first funnel.

Incorporation of a guiding panel in an inner portion of the wings to the upper portion of the first funnel ring. Guiding panel consist in a polyamide monofilament panel with $15 \mathrm{~mm}$ of stretched mesh (Fig. 1).
Except for the fan panel and guiding panel, the other components adopted in the modified shrimp fyke net were the same as the control gears: 4 main multifilament polyamide (PA multi) panels, without knots (210/12), 24 $\mathrm{mm}$ of meshes opening and cork line/lead line constituted by polyethylene braided multifilament (PE) with $8 \mathrm{~mm}$ in diameter (Fig. 2).

Table 1

Parameters of a typical artisanal-shrimp fyke net used in southern Brazil

\begin{tabular}{lc}
\hline \multicolumn{1}{c}{ Parameter } & Value/description \\
\hline Layout & 4 panels \\
Wing length & $4.50 \mathrm{~m}$ \\
Wing height & $1.60 \mathrm{~m}$ \\
Total length (without codend) & $3.10 \mathrm{~m}$ \\
Horizontal opening & $4.80 \mathrm{~m}$ \\
Codend length & $4.15 \mathrm{~m}$ \\
Codend width & $1.40 \mathrm{~m}$ \\
Distance between metal hoops & $0.60 \mathrm{~m}$ \\
Hoops diameter & $0.45 \mathrm{~m}$ \\
Stretched mesh (cod-end) & $0.024 \mathrm{~m}$ \\
Total weight (with footrope) & $7.70 \mathrm{~kg}$ \\
\hline
\end{tabular}

A

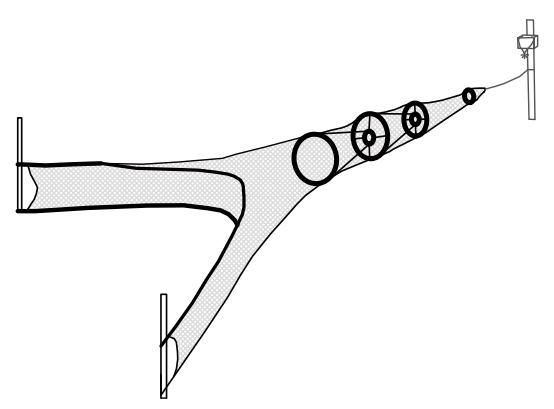

B

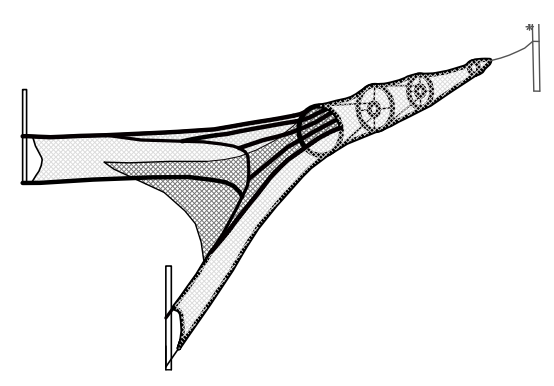

Fig. 1. Schematic layout of the control shrimp fyke net (A) and the modified shrimp fyke net used in the presently reported study (B); in (B) note the presence of fan panel between corkline to upper portion of the first valve; fan panel are constructed by PE ropes represented in figure by black lines up the mouth gear; guiding panel is attached in diagonal position between the wings ( $50 \%$ of its height) to upper portion to the first valve 
Experimental design and data analysis. To evaluate the alternative layout proposed in this work, a total of 44 sampling efforts, including 22 with a control-gear (CG) and 22 with a altered-gears (MG) along 11 fishing trials were conducted in the LEC between November 2015 and February 2016 during the shrimp-fishing season. The fishing gears were attached to bamboo stakes with an artificial light attraction for all gears in a top of codend. In all trials, the fyke nets were installed in pairs (that is, MG and CG) at the fishing area approximately at 18:00 $\mathrm{h}$ and removed approximately at $06: 00 \mathrm{~h}$, which is similar to the catching time preferred by local fishermen.

On the fishing boat, the catches were divided into two categories: shrimp (SH) and bycatch (bony fishes and blue crabs) (BC). Although the shrimp fyke nets also caught blue crabs, this fishery resource is very important to the regional economy being also considered target species. It is important to highlight that blue crabs caught by shrimp fyke nets are very important to the regional economy being considered byproduct. The fishes caught were identified to the family level and the species according to specific taxonomic keys. Additionally, Kolmogorov-Smirnov test (Siegel and Castellan 1988) was employed to check if the dataset of the main $\mathrm{SH}$ and $\mathrm{BC}$ catches in the control $(\mathrm{CG})$ and modified fyke nets (MG) were well modelled by a normal distribution. Additionally, Mann-Whitney test (Lehmann 2006) was adopted to test the statistical differences between experiments. The datasets were pooled (sum of all fishing trials) by species, considering the number of individuals and biomass by each treatment (CG or $\mathrm{MG}$ ) to compare their catch performance. Thus, it was possible to evaluate the effectiveness of each fyke net in terms of bycatch reduction. Both tests were applied considering a one-tailed distribution and a 0.05 significance level.

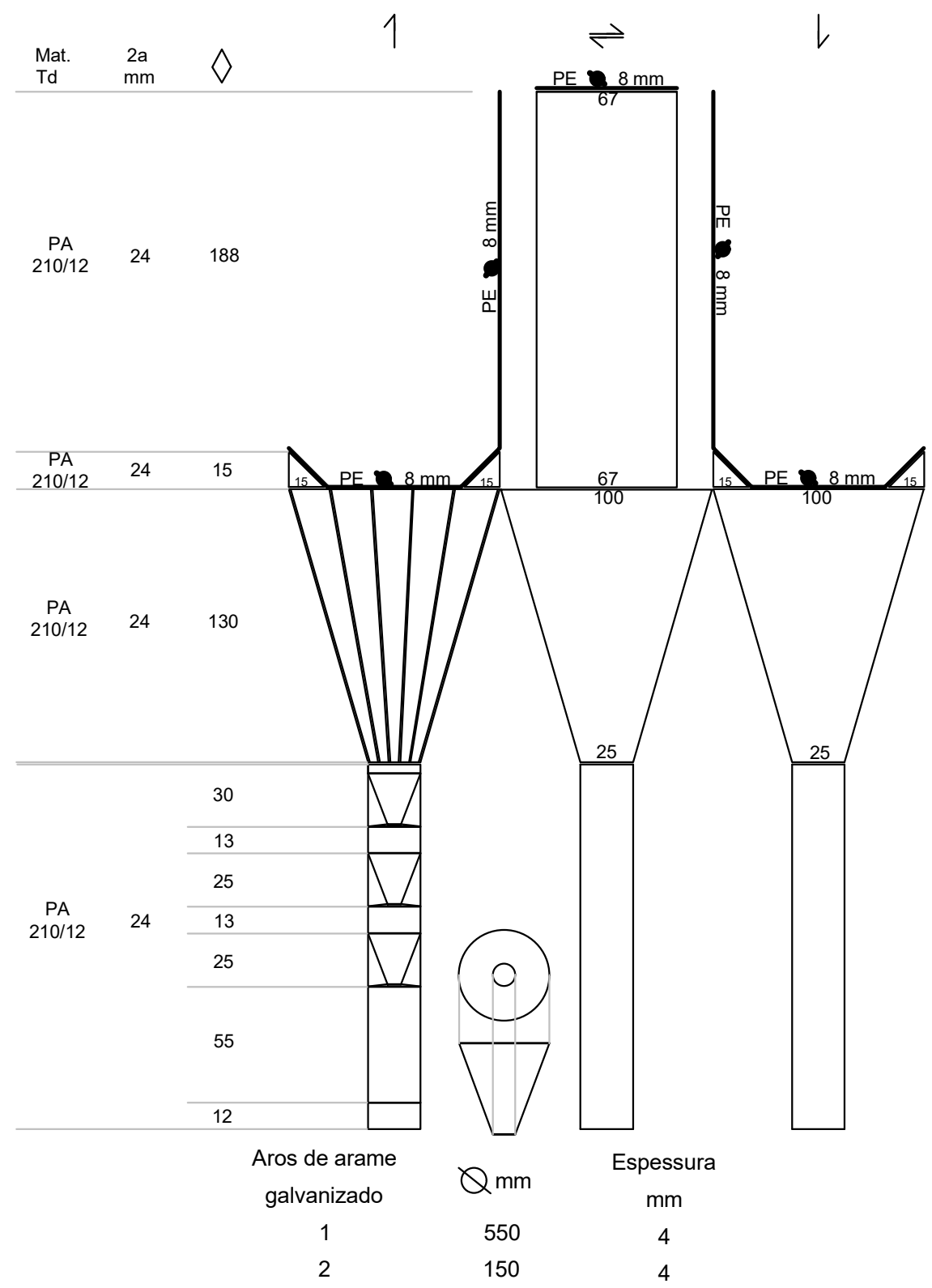

Fig. 2. Technical drawing of the modified shrimp fyke net (MG) used in the presently reported study 


\section{RESULTS}

The CG and MG fishing gears caught two shrimp species, fifteen different bony fish species, and two blue crab species (Table 2). Four bony fish species represented almost 85\% of the total bycatch: Eucinostomus gula (Quoy et Gaimard, 1824), Genidens genidens (Cuvier, 1829), Citharichthys spilopterus Günther, 1862, and Micropogonias furnieri (Desmarest, 1823). In terms of the biomass, the combined catch in CG and MG was close to $21.2 \mathrm{~kg}$, including $15.7 \mathrm{~kg}$ representing bony fishes, $5.8 \mathrm{~kg}$ of blue crabs, and just 0.2 $\mathrm{kg}$ of shrimps (target catches) (Table 2).

Kolmogorov-Smirnov test suggested that our dataset could not be analysed through the parametric approach. So, paired Mann-Whitney non-parametric test was employed to evaluate the BRD impacts on the bycatch reductions in shrimp fyke nets (Table 3). For the total number and biomass of bycatch, significant differences were observed $(P<0.05)$, showing that altered shrimp fyke nets (MG) had a significant potential for bycatch reduction (Table 3). MG presented a better selectivity performance ( 228 bony fishes weighing $3519.74 \mathrm{~g}$ ) than control fyke nets (CG) (719 bony fishes weighing 12 $215.90 \mathrm{~g}$ ). These results suggest that $\mathrm{MG}$ can reduce by more than 65 percentage points the bycatch acquisition.

For all main bony fishes in bycatch (E. gula, G. genidens, C. spilopterus, and M. furnieri), significant differences were observed in the number of individuals and biomass $(P<0.05)$, between MG and CG (Table 3 ). Micropogonias furnieri was the main bony fish caught in control and modified shrimp fyke nets (400 individuals), including 309 individuals (6129.20 g) in CG and 91 (1447.42 g) in MG, followed by E. gula (209 individuals) where 153 individuals $(1564.20 \mathrm{~g})$ were caught in CG and 56 individuals (608.08 g) in MG (Figs. 3 and 4; Table $2)$. The third most representative bycatch species was G. genidens, with 94 (1639.20 g) and 40 (693.40 g) individuals caught in $\mathrm{CG}$ and $\mathrm{MG}$, respectively. Finally, the fourth highest occurrence bycatch species found in $\mathrm{CG}$ and MG was C. spilopterus (60 individuals) with a predominance of catches in CG (52 individuals weighing $536.20 \mathrm{~g}$ ) against 8 individuals, weighing $53.38 \mathrm{~g}$, caught in MG (Figs. 3 and 4, Table 2).

All bony fishes caught ( $\mathrm{CG}$ and $\mathrm{MG}$ ) had total lengths below the $L_{50}$ (length at which $50 \%$ of the fish are mature). Micropogonias furnieri represented mean length of 12.2 $\mathrm{cm}$ (standard deviation $=3.4 \mathrm{~cm}$ ), for E. gula the mean length was $9.9 \mathrm{~cm}$ (standard deviation $=1.3 \mathrm{~cm}$ ) and G. genidens showed mean length close to $11 \mathrm{~cm}$ (standard deviation $=3.78 \mathrm{~cm}$ ). Finally, $C$. spilopterus had the mean length of $8.4 \mathrm{~cm}$ and standard deviation of $2.9 \mathrm{~cm}$ in CG and MG. Note in Fig. 5 that all bony fishes caught had a similar total length and standard deviation.

Table 2

Number of individuals, biomass, and mean total length of crustaceans and bony fishes caught using the control shrimp fyke net $(\mathrm{CG})$ and the modified shrimp fyke $(\mathrm{MG})$ in the Laguna Estuarine Complex, southern Brazil, in 2016

\begin{tabular}{|c|c|c|c|c|c|c|c|}
\hline \multirow[t]{2}{*}{ Family } & \multirow[t]{2}{*}{ Scientific name } & \multicolumn{2}{|c|}{$\begin{array}{c}\text { Number } \\
\text { of individuals }\end{array}$} & \multicolumn{2}{|c|}{ Biomass $[\mathrm{g}]$} & \multicolumn{2}{|c|}{$\begin{array}{c}\text { Mean } \\
\text { length }[\mathrm{cm}]\end{array}$} \\
\hline & & CG & MG & CG & MG & CG & MG \\
\hline \multicolumn{8}{|l|}{ Crustaceans } \\
\hline Penaeidae & Litopenaeus schmitti & 2 & 3 & 17.80 & 19.80 & 10.90 & 12.50 \\
\hline Penaeidae & Farfantepenaeus paulensis & 20 & 11 & 89.90 & 49.89 & 8.25 & 9.00 \\
\hline Portunidae & Callinectes sapidus & 93 & 34 & 3866.60 & 1542.69 & 8.75 & 9.60 \\
\hline Portunidae & Callinectes danae & 1 & 1 & 35.80 & 45.56 & 8.20 & 9.30 \\
\hline Total of crustaceans & & 116 & 49 & 4010.10 & 1657.94 & & \\
\hline \multicolumn{8}{|l|}{ Bony fishes } \\
\hline Achiridae & Achirus lineatus (Linnaeus, 1758) & 43 & 1 & 242.40 & 4.77 & 7.05 & 6.00 \\
\hline Ariidae & Genidens genidens (Cuvier, 1829) & 94 & 40 & 1639.20 & 693.40 & 11.35 & 10.70 \\
\hline Atherinopsidae & Atherinella brasiliensis (Quoy et Gaimard, 1825) & 1 & 0 & 10.30 & 0.00 & 13.00 & 0.00 \\
\hline Belonidae & Strongylura timucu (Walbaum, 1792) & 5 & 1 & 761.70 & 43.11 & 46.30 & 34.50 \\
\hline Carangidae & Oligoplites saliens (Bloch, 1793) & 4 & 0 & 116.60 & 0.00 & 16.20 & 0.00 \\
\hline Carangidae & Oligoplites saliens (Bloch, 1793) & 4 & 0 & 116.60 & 0.00 & 16.20 & 0.00 \\
\hline Centropomidae & Centropomus parallelus Poey, 1860 & 1 & 0 & 5.20 & 0.00 & 9.20 & 0.00 \\
\hline Curimatidae & $\begin{array}{l}\text { Cyphocharax santacatarinae (Fernández-Yépez, } \\
\text { 1948) }\end{array}$ & 0 & 1 & 0.00 & 7.09 & 0.00 & 8.50 \\
\hline Engraulidae & Anchoa marinii Hildebrand, 1943 & 1 & 0 & 5.60 & 0.00 & 9.40 & 0.00 \\
\hline Gerreidae & Diapterus rhombeus (Cuvier, 1829) & 18 & 5 & 187.80 & 61.58 & 9.00 & 9.70 \\
\hline Gerreidae & Eucinostomus gula (Quoy et Gaimard, 1824) & 153 & 56 & 1564.20 & 608.08 & 9.90 & 10.20 \\
\hline Gobiidae & Gobionellus oceanicus (Pallas, 1770) & 3 & 4 & 54.00 & 60.00 & 15.80 & 14.30 \\
\hline Mugilidae & Mugil curema Valenciennes, 1836 & 2 & 0 & 124.70 & 0.00 & 13.55 & 0.00 \\
\hline Paralichthyidae & Citharichthys spilopterus Günther, 1862 & 52 & 8 & 536.20 & 53.38 & 8.35 & 8.55 \\
\hline Sciaenidae & Micropogonias furnieri (Desmarest, 1823) & 309 & 91 & 6129.20 & 1447.42 & 12.45 & 12.00 \\
\hline Total of bony fishes & & 719 & 228 & 12215.90 & 3519.74 & & \\
\hline
\end{tabular}


Table 3

The numerical and biomass effectiveness of the control shrimp fyke net versus the modified shrimp fyke net tested in the Laguna Estuarine Complex, southern Brazil, in 2016 expressed as paired Mann-Whitney statistics

\begin{tabular}{lcc}
\hline & $\begin{array}{c}\text { Mann-Whitney } \\
\text { Test U }\end{array}$ & Status \\
\hline Number of individuals, bony fishes & & \\
$\quad$ Citharichthys spilopterus & 118.5 & $P<0.05$ \\
Eucinostomus gula & 103.8 & $P<0.05$ \\
Genidens genidens & 125.5 & $P<0.05$ \\
Micropogonias furnieri & 88.5 & $P<0.05$ \\
Number of individuals, shrimps & & \\
Farfantepenaeus paulensis & - & $\mathrm{NS}$ \\
Litopenaeus schimitti & 37 & $\mathrm{NS}$ \\
Number of individuals, blue crabs & & \\
Callinectes danae & 439 & $P<0.05$ \\
Callinectes sapidus & 37.5 & $P<0.05$ \\
Biomass, blue crabs & & \\
$\quad$ Callinectes danae & 480 & $P<0.05$ \\
Callinectes sapidus & 40 & $P<0.05$ \\
Biomass, bony fishes & & \\
Citharichthys spilopterus & 282 & $P<0.05$ \\
Eucinostomus gula & 284 & $P<0.05$ \\
Genidens genidens & 329 & $P<0.05$ \\
Micropogonias furnieri & 443 & $P<0.05$ \\
Biomass, shrimps & & \\
Farfantepenaeus paulensis & - & $\mathrm{NS}$ \\
Litopenaeus schimitti & 101.5 & $\mathrm{NS}$ \\
\hline NS not significant. & &
\end{tabular}

$\mathrm{NS}=$ not significant

The non-parametric test showed that there were no significant differences of shrimp catches between the fishing gears used (MG and $\mathrm{CG}$ ). Therefore, the BRD reduced the bony fishes acquisition preserving the volume of target catches. In addition, the mean length of the shrimps showed an increment in the MG, compared to $\mathrm{CG}$ (Table 2). The blue crab Callinectes sapidus showed significant differences in the number and biomass, between CG and MG $(P<$ 0.05) (Table 3). The CG caught 20 individuals (1097.1 g) and MG 8 individuals (220.57 g), but the mean length of the individuals was higher in MG than in CG. Similar statistical patterns were found in Callinectes danae, which was possible to identify differences between $\mathrm{CG}$ and $\mathrm{MG}$ in number and biomass $(P<0.05)$. Details about the species caught and statistics results are presented in Tables 2 and 3.

\section{DISCUSSION}

The results of this study demonstrate that simple structural alterations in a conventional fishing gear can contribute to an increase in its selectivity. In this case, the use of a guiding panel associated with a fan upper panel reduced by 66 percentage points the bycatch acquisition without affecting significantly the shrimp catches. However, compared to previous studies (Vieira et al. 1996, Loebmann and Vieira 2006, Vianna and D'Incao 2006) the absolute shrimp catches obtained in this study (regardless of the treatment) were distinctly lower than those reported in other years.

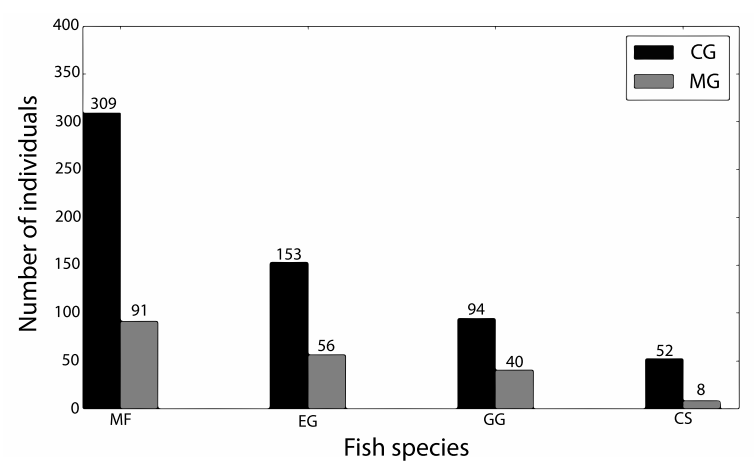

Fig. 3. The numerical effectiveness of the control shrimp fyke net $(\mathrm{CG})$ versus the modified shrimp fyke (MG), tested in the Laguna Estuarine Complex, southern Brazil, in 2016, in respect to the main four bycatch species caught; $\mathrm{MF}=$ Micropogonias furnieri, $\mathrm{EG}=$ Eucinostomus gula, $\mathrm{GG}=$ Genidens genidens, $\mathrm{CS}=$ Citharichthys spilopterus

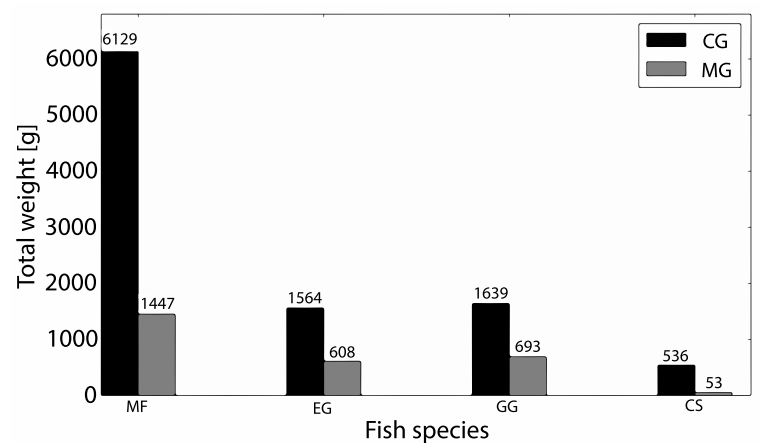

Fig. 4. The biomass effectiveness of the control shrimp fyke net $(\mathrm{CG})$ versus the modified shrimp fyke (MG), tested in the Laguna Estuarine Complex, southern Brazil, in 2016, in respect to the main four bycatch species caught; $\mathrm{MF}=$ Micropogonias furnieri, $\mathrm{EG}=$ Eucinostomus gula, $\mathrm{GG}=$ Genidens genidens, $\mathrm{CS}=$ Citharichthys spilopterus

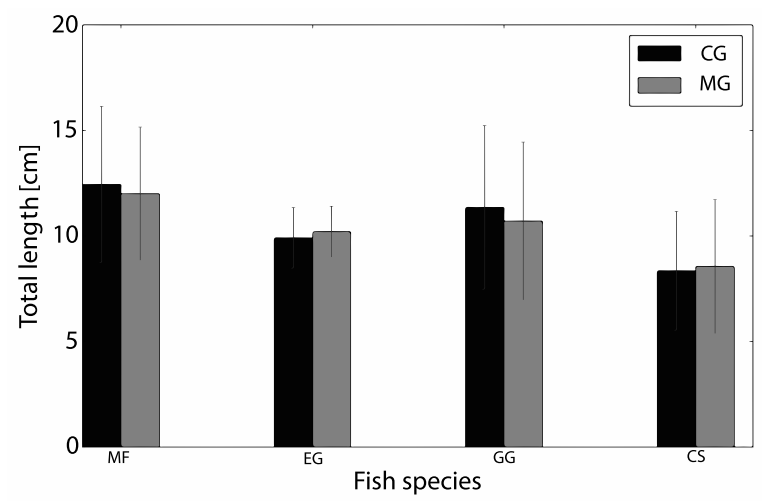

Fig. 5. Length (TL) comparison of main four bycatch species caught using control shrimp fyke net (CG) versus the modified shrimp fyke (MG), tested in the Laguna Estuarine Complex, southern Brazil, in 2016; bars represent main values while whiskers represent standard deviation; $\mathrm{MF}=$ Micropogonias furnieri, $\mathrm{EG}=$ Eucinostomus gula, $\mathrm{GG}=$ Genidens genidens, $\mathrm{CS}=$ Citharichthys spilopterus 
Possibly, the lower shrimp catch rates observed in the presently reported study were related to the El Niño events between 2015 and 2016. Usually, El Niño is associated with positive precipitation anomalies in southern Brazil (Grimm et al. 2000). This fact was previously observed by Vianna and D'Incao (2006) and Santana et al. (2015). These authors found a negative correlation between El Niño events and shrimp catches in South America. Möller et al. (2009) suggested that the increase in estuarine hydrodynamic flows due to the water input derived from the precipitation constitutes a physical barrier, limiting the entry of shrimps into transitional environments. According to Möller et al. (2009), the increase in estuarine flows is more evident in environments with narrow estuary-sea interfaces, which can be observed in the LEC.

The bycatch composition found in the presently reported study was similar to that in previous studies (Vieira et al. 1996, Loebmann and Vieira 2006) including the abundance of some bony fish species. In this study, Eucinostomus gula, Genidens genidens, Citharichthys spilopterus, and Micropogonias furnieri were the most prominent bycatch items in the presently reported study. In general terms, these species inhabiting estuarine shallow waters, especially during the early stages of their life cycle once these environments can provide food and shelter for these potential fisheries resources (Barletta et al. 2008, Lacerda et al. 2014).

The alternative layout, proposed in this study, presented good performance in terms of reduction of demersal fish catches. According to Marchesan et al. (2009), when exposed to artificial light, fish species with diurnal habits perform a vertical migration even in shallow environments. Thus, possibly the low capture of these species by MG, is directly associated with the vertical opening limitation.

Blue crabs are not usually the target species of the fyke nets fisheries, but due to the low catches of shrimps, during El Nino events, Callinectes danae and Callinectes sapidus are treated as a secondary target species and retained for marketing, in order to increase the income of fishermen. In the presently reported study, the blue crab catch was reduced in the MG treatment, but the mean length of the individuals increased, showing a better selectivity and excluded small individuals.

The vertical opening reduction due to the adoption of the guiding panel + fan upper panel contributed to bycatch reduction, resulting in an increase the shrimp fyke net selectivity and a reduction of the potential impacts of the traditionally used, unaltered fyke net over the bony fish stocks.

The absence of statistically significant differences between the shrimp catches in CG and MG will be reviewed in future works. Although this information suggests that the alternative layout can concatenate selectivity with the maintenance of shrimp catches on the unchanged level, the low occurrence of target species acquisition was possibly associated with the El Niño phenomenon. Therefore, it is pertinent to repeat this experiment under the usual meteorological conditions in the LEC. Thus, the statistical tests applied may be ratified.
Considering the relevance of this subject to artisanal fisheries development, new experiments need to be encouraged to improve the fishing gear selectivity in the regional context.

\section{ACKNOWLEDGEMENTS}

This study was a part of CNPq UNIVERSAL program (448568/2014-4), which was funded by the Conselho Nacional de Desenvolvimento Científico e Tecnológico (CNPq). Additionally, authors thank for the support of the Grupo de Gestão, Ecologia e Tecnologia Marinha (GTMar) from the Departamento de Engenharia de Pesca e Ciências Biológicas, Universidade do Estado de Santa Catarina (UDESC)/Laguna (NPP20150000454).

\section{REFERENCES}

Andrew N.L., Kennelly S.J., Broadhurst M.K. 1993. An application of the Morrison soft TED to the offshore prawn fishery in New South Wales, Australia. Fisheries Research 16 (2): 101-111. DOI: 10.1016/01657836(93)90046-A

Barletta M., Amaral C.S., Corrêa M.F.M., Guebert F., Dantas D.V., Lorenzi L., Saint-Paul U. 2008. Factors affecting seasonal variations in demersal fish assemblages at an ecocline in a tropical-subtropical estuary. Journal of Fish Biology 73 (6): 1314-1336. DOI: 10.1111/j.1095-8649.2008.02005.x

Barletta M., Lima A.R.A., Dantas D.V., Oliveira I.M., Reis Neto J., Fernandes C.A.F., Farias E.G.G., Filho J.L.R., Costa M.F. 2017. [Chapter 20] How can accurate landing stats help designing better fisheries and environmental management for western Atlantic estuaries? Pp. 631-703. In: Finkl C.W., Makowski C. (eds.). Coastal wetlands: Alteration and remediation. Coastal Research Library book series Vol. 21. Springer Nature. DOI: 10.1007/978-3-319-56179-0_20

Benedet R.A., Dolci D.B., D'Incao F. 2010. Descrição técnica e modo de operação das artes de pesca artesanais do camarão-rosa no estuário da Lagoa dos Patos, Rio Grande do Sul, Brasil. [Technical description and mode of operation of the artisanal fishing gear of the pink shrimp in the estuary of Lagoa dos Patos, Rio Grande do Sul, Brazil.] Atlântica 32 (1): 5-24. [In Portuguese.]

Branco J.O., Verani J.R. 2006. Análise qualiquantitativa da ictiofauna acompanhante da pesca do camarão sete-barbas na armação do Itapocoroy, Penha, Santa Catarina. [Quali-quantitative analysis of seabob-shrimp's ichthyofauna bycatch, at Armação do Itapocoroy, Penha, Santa Catarina.] Revista Brasileira de Zoologia 23 (2): 381-391. [In Portuguese.] DOI: 10.1590/S0101-81752006000200011

Broadhurst M.K. 2000. Modifications to reduce bycatch in prawn trawls: A review and framework for development. Reviews in Fish Biology and Fisheries 10 (1): 27-60. DOI: 10.1023/A:1008936820089

Broadhurst M.K., Kennelly S.J. 1996. Effects of the circumference of codends and a new design of square-mesh panel in reducing unwanted by-catch in 
the New South Wales oceanic prawn-trawl fishery, Australia. Fisheries Research 27 (4): 203-214. DOI: 10.1016/0165-7836(95)00469-6

Cattani A.P., Bernardo C., Medeiros R.P., Santos L.O., Spach H.L. 2012. Avaliação de dispositivos para redução da ictiofauna acompanhante na pesca de arrasto dirigida ao camarão sete-barbas. [An assessment of a bycatch-reduction device in the seabob shrimp fishery.] Boletim do Instituto de Pesca 38 (4): 333-348. [In Portuguese.]

Colotelo A.H., Cooke S.J., Blouin-Demers G., Murchie K.J., Haxton T., Smokorowski K.E. 2013. Influence of water temperature and net tending frequency on the condition of fish bycatch in a small-scale inland commercial fyke net fishery. Journal for Nature Conservation 21 (4): 217-224. DOI: 10.1016/j. jnc.2013.01.001

D'Incao F., Valentini H., Rodrigues L.F. 2002. Avaliação da pesca de camarões nas regiões sudeste e Sul do Brasil (1965-1999). [An assessment of the shrimp fishery in the south-eastern and southern regions of Brazil (1965-1999).] Atlântica 24 (2): 103-116. [In Portuguese.]

Domingos M.M., Rodrigues-Filho J.L., Farias E.G.G. 2016. Avaliação de uma rede-de-arrasto camaroeira estruturalmente modificada. [Evaluation of a structurally modified shrimp trawl net.] Boletim do Instituto de Pesca 42 (2): 353-368. [In Portuguese.] DOI: $10.20950 / 1678-2305.2016 v 42 n 2 p 353$

Grimm A.M., Barros V.R., Doyle M.E. 2000. Climate variability in southern South America associated with El Niño and La Niña events. Journal of Climate 13 (1): 35-58. DOI: 10.1175/1520-0442(2000)013<0035:CVISSA > 2.0.CO;2

Lacerda C.H.F., Barletta M., Dantas D.V. 2014. Temporal patterns in the intertidal faunal community at the mouth of a tropical estuary. Journal of Fish Biology 85 (5): 1571-1602. DOI: 10.1111/jfb.12518

Larocque S.M., Cooke S.J., Blouin-Demers G. 2012. Mitigating bycatch of freshwater turtles in passively fished fyke nets through the use of exclusion and escape modifications. Fisheries Research 125-126: 149-155. DOI: 10.1016/j.fishres.2012.02.018

Lehmann E.L. 2006. Nonparametrics: Statistical methods based on ranks. Springer, New York NY, USA.

Loebmann D., Vieira J.P. 2006. O impacto da pesca do camarão-rosa Farfantepenaeus paulensis (PerezFarfante) (Decapoda, Penaeidae) nas assembléias de peixes e siris do Parque Nacional da Lagoa do Peixe, Rio Grande do Sul, Brasil. [The impact of the pink shrimp Farfantepenaeus paulensis (Perez-Farfante) (Decapoda, Penaeidae) fishery on the fish and crab assemblages of the Lagoa do Peixe National Park, Rio Grande do Sul, Brazil.] Revista Brasileira de Zoologia 23 (4): 1016-1028. [In Portuguese.] DOI: 10.1590/ S0101-81752006000400006

Marchesan M., Spoto M., Ferrero E.A. 2009. Impact of artificial light on behavioural patterns of coastal fishes of conservation interest. Varstvo Narave 22: 117-136.

Marques J.S., Müller I.C., Moser J.R., Sincero T.C., Marques M.R.F. 2011. Wild captured crab, Chasmagnathus granulata (Dana, 1851), a new host for white spot syndrome virus (WSSV). Aquaculture 318 (1-2): 20-24. DOI: 10.1016/j.aquaculture.2011.04.031

Möller O.O., Castello J.P., Vaz A.C. 2009. The effect of river discharge and winds on the interannual variability of the pink shrimp Farfantepenaeus paulensis production in Patos Lagoon. Estuaries and Coasts 32 (4): 787-796. DOI: 10.1007/s12237-009-9168-6

Santana O., Silveira S., Fabiano G. 2015. Catch variability and growth of pink shrimp (Farfantepenaeus paulensis) in two coastal lagoons of Uruguay and their relationship with ENSO events. Brazilian Journal of Oceanography 63 (3): 355-362. DOI: $10.1590 /$ S167987592015103306303

Siegel S., Castellan J.N.jr. 1998. Nonparametric statistics for the behavioral sciences. 2nd edn. McGraw-Hill, New York NY, USA.

Soeth M., Ribeiro G.C., Spach H.L., Cattani A.P., Andrade V.K. 2015. Comparison of the temporal and taxonomic patterns of ichthyofauna captured with a fyke net in two sheltered environments in southern Brasil. Latin American Journal of Aquatic Research 43 (1): 107-122. DOI: 10.3856/vol43-issue1-fulltext-10

Vianna M., D'Incao F. 2006. Evalution of by-catch reduction devices for use in the artisanal pink shrimp (Farfantepenaeus paulensis) fishery in Patos Lagoon, Brazil. Fisheries Research 81 (2): 331-336. DOI: 10.1016/j.fishres.2006.06.011

Vieira J.P., Vasconcellos M.C., Silva R.E.E., Fisher L.G.F. 1996. A rejeição da pesca do camarão-rosa (Penaeus paulensis) no estuário da Lagoa dos Patos, RS, Brasil. [Rejection of fishing for pink shrimp (Penaeus paulensis) in the estuary of Lagoa dos Patos, RS, Brazil.] Atlântica 18: 123-142. [In Portuguese.]

Vieira W.J., Domingos M.M., Rodrigues-Filho J.L., Farias E.G.G. 2017. Kite escape device: A new approach to reduce bycatch in shrimp trawls. Marine and Coastal Fisheries 9 (1): 396-403. DOI: 10.1080/19425120.2017.1347114

Received: 6 December 2017

Accepted: 11 October 2018 Published electronically: 15 March 2019 